\title{
WiLl THE LAW SOCIETY OF ALBERTA \\ Celebrate its BiCENTENARY?
}

\author{
HARRY W. ARTHURS*
}

External changes - in demography and economy, in the domestic and global organization of powerare transforming the knowledge base of Canada's legal profession, the relations amongst lawyers and between lawyers and their "relevant others," and indeed the very notion of legal professionalism. This article explores the implication of these changes for the future of the profession's governing bodies.

\begin{abstract}
Les changements externes - dans la démographie et l'économie, dans l'organisation nationale et mondiale du pouvoir - transforment la base de connaissances de la profession juridique du Canada, des relations entre avocats et entre avocats et leurs "personnes pertinentes», ainsi que de la notion proprement dite de professionnalisme juridique. Cet article explore l'implication de ces changements pour l'avenir des organismes régissant la profession.
\end{abstract}

\section{TABLE OF CONTENTS}

I. INTRODUCTION: THE LINK BETWEEN PROFESSIONAL

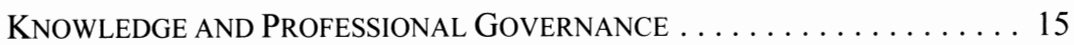

II. THE EFFECT OF EXTERNAL CHANGE ON LEGAL

ORganizATION AND PROFESSIONALISM $\ldots \ldots \ldots \ldots \ldots \ldots \ldots$

III. GLOBALIZATION AND THE ERODING LOGIC OF

Local Professional Governance $\ldots \ldots \ldots \ldots \ldots \ldots \ldots \ldots . \ldots \ldots$

IV. HyPhenated Professionalism: The Most Fundamental

Challenge to Professional Governance . . . . . . . . . . . . 24

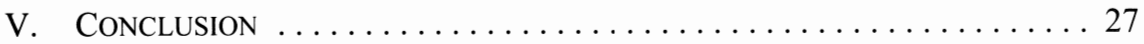

\section{Introduction: The Link Between ProfessionaL KNOWLEdge AND Professional GovernanCE}

The title of this essay, "Will the Law Society of Alberta Celebrate its Bicentenary?" is intended not as a prediction of impending doom, but rather as an acknowledgment that things change. Things change not only inside the legal profession, but also and especially outside it in society, in the economy, in our political system, and in our natural environment. Those external changes, I will argue, are the primary drivers of internal change. These drivers are so powerful that they are transforming not only legal processes and institutions, not only the profession's clientele and competitive environment, not only the technology and economics of practice, but the very essence of what makes law a profession. ${ }^{1}$

University Professor Emeritus and President Emeritus, Osgoode Hall Law School, York University. An earlier version of this article was delivered as a keynote address at the Law Society of Alberta's 100th Anniversary Conference in Edmonton, Alberta on 26 October 2007. I am grateful for the research assistance provided by Andrew Reynolds and Scott Jones.

$1 \quad$ See Harry W. Arthurs \& Robert Kreklewich, "Law, Legal Institutions, and the Legal Profession in the New Economy" (1996) 34 Osgoode Hall L.J. 1; Harry W. Arthurs, "The State We're In: Legal Education in Canada's New Political Economy" (2001) 20 Windsor Y.B. Access Just. 35 [Arthurs, "The State We're In']. 
Professions are founded on two premises. ${ }^{2}$ The first is that members of the profession know things other people do not. Some of those things they learn from books, others from experience, but always a core body of knowledge is supposedly shared by the members of the profession. Acquiring this body of knowledge is how one gains admission to the profession, and not having a credential which attests to possessing it disqualifies one from doing professional work. ${ }^{3}$ The second premise is that their work requires that professionals be allowed to do things forbidden to other people, and vice versa. What can and cannot be done is sometimes laid down by law, sometimes inscribed in formal codes governing professional conduct, and sometimes embedded in cultural practices and traditions. This second premise explains why professions are licensed monopolies and why almost all are at least semi-autonomous and many self-regulating. ${ }^{4}$

Alas, both premises underpinning professionalism have less and less relevance to Canada's legal profession. Lawyers share knowledge less and less with other lawyers, and more and more with people in adjacent lines of work. And lawyers adhere less and less to common codes of conduct, live less and less within a common professional culture, behave more and more like other people, and enjoy dwindling, though still considerable, autonomy.

I am not going to debate whether the decline and fall of legal professionalism might be a good thing or a bad one. Rather I will explain how and why it is happening and sketch out the likely consequences. In each case, I will identify a development out there in the world and then try to show how that development has altered the bar's knowledge base and, ultimately, its political economy, culture, solidarity, autonomy, and governance structures.

\section{The EfFect OF EXTERnAL Change ON Legal ORganization AND PROFESSIONALISM}

I will begin with demographic changes that have occurred since the Law Society of Alberta (LSA) was founded 100 years ago. Canada's population has shifted westwards; it has moved from the countryside to the cities; affluence has increased along with economic inequality; immigration has declined as a percentage of the country's population, but

2 One extensive body of sociological literature suggests that professions define themselves in order to control markets. See e.g. Eliot Freidson, Profession of Medicine: A Study of the Sociology of Applied Knowledge (New York: Dodd, Mead, 1970); Terence J. Johnson, Professions and Power (London: Macmillan, 1972); Magali Sarfatti Larson, The Rise of Professionalism: A Sociological Analysis (Berkeley: University of California Press, 1977). In a law-specific context, see e.g. Richard L. Abel, "Comparative Sociology of Legal Professions" in Richard L. Abel \& Philip S.C. Lewis, eds., Lawyers in Society (Berkeley: University of California Press, 1989) 80; Richard L. Abel, "Toward a Political Economy of Lawyers" (1981) Wis. L. Rev. 1117; Richard L. Abel, "The Decline of Professionalism?" (1986) 49 Mod. L. Rev. 1. Contra Miek Berends, “An Elusive Profession? Lawyers in Society" (1992) 26 Law \& Soc'y Rev. 161; Alan A. Paterson, "Professionalism and the Legal Services Market” (1996) 3 Int'l J. Legal Prof. 137.

3 See e.g. Legal Profession Act, R.S.A. 2000, c. L-8, ss. 106-11; Law Society Act, R.S.O. 1990, c. L-8, ss. 26.1-26.3. The consequences of unauthorized practice are potentially serious: a paralegal in Ontario was recently sentenced to four months house arrest for the unauthorized practice of law. See Kirk Makin, "Paralegal sentenced to house arrest" The Globe and Mail (3 October 2007) A8.

4 See e.g. Bruce L. Arnold \& Fiona M. Kay, "Social Capital, Violations of Trust and the Vulnerability of Isolates: The Social Organization of Law Practice and Professional Self-Regulation" (1995) 23 Int'l J. Soc. L. 321. 
increased in terms of the variety of countries, cultures, and creeds represented amongst our newest communities; the generational balance between young and old has tipped; and, of course, gender roles have been transformed. ${ }^{5}$

These demographic changes have fundamentally altered Canada's political economy and, inevitably, that of the profession as well. ${ }^{6}$ Rural societies - like Alberta in 1907 - typically generated little investment capital, supported a short list of businesses, and developed fairly basic forms of social relations and social controls. But greater affluence brings more intense debates over the generation, protection, taxation, and redistribution of wealth; greater inequality and ethno-cultural diversity bring more intense concerns about human rights; urbanization brings greater possibilities for the specialization of economic functions and greater need for and the possibility of the provision of public goods and services; and shifts in the generational balance and in gender roles bring new social tensions and generate the need for new institutions to mediate those tensions. ${ }^{7}$

These demographic changes made possible and necessary the development of fields of legal practice that the founding fathers of the LSA would never have been able to imagine: taxation and consumer law, human rights and refugee law, land use and environmental law, labour law, intellectual property law, estate planning, and energy law. These new, specialized fields of practice are defined by new, specialized forms of knowledge. Obviously, that new knowledge is only distantly related to what lawyers knew in $1907 .^{8}$ Less obviously, it is

5 See e.g. Warren E. Kalbach \& Wayne W. McVey, The Demographic Bases of Canadian Society, $2 \mathrm{~d}$ ed. (Toronto: McGraw-Hill Ryerson, 1979); Mary Anne Burke, "Interregional Migration of the Canadian Population" in Frank Trovato \& Carl F. Grindstaff, eds., Perspectives on Canada's Population: An Introduction to Concepts and Issues (Toronto: Oxford University Press, 1994) 313; Leroy O. Stone, "Urban Development in Canada" in Trovato \& Grindstaff, ibid., 365.

Selected works on the history of the Alberta legal profession include: Louis Knafla \& Richard Klumpenhouwer, Lords of the Western Bench: A Biographical History of the Supreme and District Courts of Alberta, 1876-1990 (Calgary: Legal Archives Society of Alberta, 1997); Peter M. Sibenik, "Points of Departure: Urban Relief in Alberta, 1930-1937" in Louis A. Knafla, ed., Law \& Justice in a New Land: Essays in Western Canadian Legal History (Toronto: Carswell, 1986) 313; Peter M. Sibenik, “"The Black Sheep': The Disciplining of Territorial and Alberta Lawyers, 1885-1928” (1988) 3 C.J.L.S. 109; Law Society of Alberta, Just Works: Lawyers in Alberta 1907-2007 (Toronto: Irwin Law, 2007). See also W. Wesley Pue, "Cowboy Jurists and the Making of Legal Professionalism" (2008) 45:5 Alta. L. Rev. 29. For a review of the growth and research into legal history in Alberta, see John P.S. McLaren, "Meeting the Challenges of Canadian Legal History: The Albertan Contribution"(1994) 32 Alta. L. Rev. 423. Related works on the legal professions of other western provinces include: W. Wesley Pue, Lawyers and the Constitution of Political Society: Containing Radicalism and Maintaining Order in Prairie Canada, 1900-1930 (Winnipeg: Faculty of Law, University of Manitoba, 1993); Lee Gibson, "A Brief History of the Law Society of Manitoba" in Cameron Harvey, ed., The Law Society of Manitoba 1877-1977 (Winnipeg: Peguis, 1977) 28; Roland Dale Brawn, Paths to the Bench: Judicial Appointments in Manitoba, 1872-1850 (LL.D. Thesis, Osgoode Hall Law School, 2003); W. Wesley Pue, "Cultural Projects and Structural Transformation in the Canadian Legal Profession" in W. Wesley Pue \& David Sugarman, eds., Lawyers and Vampires: Cultural Histories of Legal Professions (Portland, Or.: Hart, 2003) 367.

7 For development of these themes in a United States context, see e.g. Lawrence M. Friedman, $A$ History of American Law, 2d ed. (New York: Simon \& Shuster, 1985) at 662-95; Robert W. Gordon, "Critical Legal Histories" (1984) 36 Stan. L. Rev. 57.

8 See W. Wesley Pue, “Common Law Legal Education in Canada's Age of Light, Soap and Water" (1995) 23 Man. L.J. 654; W. Wesley Pue, "British Masculinities, Canadian Lawyers: Canadian Legal Education, 1900-1930” (1999) 16 Law in Context 80; David A.A. Stager \& Harry W. Arthurs, Lawyers in Canada (Toronto: University of Toronto Press, 1990) at 86-93. 
almost equally different from what was taught in law schools as recently as, say, 1967 or 1987. ${ }^{9}$ Moreover, specialists do not just become immersed in the new knowledge; they tend to abandon the old. Further, the key point: specialists do not simply read different texts and law reports and develop different skill sets and experiential knowledge; they tend also to serve different clienteles, to speak to them in different vernaculars, and to charge fees which are a different order of magnitude from those charged by other lawyers. ${ }^{10}$ And finally, a point I will return to below, the trend to specialization in the legal profession has closely tracked the trend to stratification.

And now a paradox: while specialized knowledge is moving lawyers farther and farther away from most of their professional colleagues, it is moving them closer and closer to their "relevant others." If you are an energy lawyer, you will want to walk the walk and talk the talk of the oil and gas industry; if you are a labour lawyer, your "relevant others" are Human Resources managers and union officials; and if you are a tax lawyer, you will be spending a lot of time with accountants. Good lawyering for specialists, then, tends to immerse them in adjacent bodies of non-legal knowledge.

Where do general practitioners fit into this picture? They too deploy specialized knowledge, both legal and non-legal, but its depth and breadth is determined by the modest needs and means of their clientele - typically middle- and working-class individuals, and small- or medium-sized businesses. These clients need wills and divorces; they need to incorporate companies and be helped through routine transactions; they need to collect debts and be defended in lower-level civil, criminal, and regulatory proceedings. But they usually do not need - and often cannot afford - the new legal knowledge dispensed by large law firms with their specialized departments. Consequently, compared to specialists, the knowledge base of general practitioners more closely resembles that of their predecessors in 1907.

These disparities in knowledge lead to stratification - to the establishment of a pecking order within the legal community. ${ }^{11}$ By and large, specialists enjoy higher economic, social, and professional status than general practitioners. ${ }^{12}$ There are exceptions: generalists still count for something in small towns, and they may still make their mark in the general legal community, if they are people of unusual character or talents. However, most general

9 H.W. Arthurs, “A Lot of Knowledge is a Dangerous Thing: Will the Legal Profession Survive the Knowledge Explosion?" (1995) 18 Dal. L.J. 295; Constance Backhouse, "The Changing Landscape of Canadian Legal Education" (2001) 20 Windsor Y.B. Access Just. 25; Arthurs, "The State We're In," supra note 1; Annie Rochette \& W. Wesley Pue, “'Back to Basics'? University Legal Education and 21 st Century Professionalism” (2001) 20 Windsor Y.B. Access Just. 167. Arthurs, "The State We're In," supra note 1.

11 The leading work on stratification and its effects on solo practitioners and small firms is John P. Heinz et al., Urban Lawyers: The New Social Structure of the Bar (Chicago: University of Chicago Press, 2005).

12 For studies on the stratification of the Canadian legal profession, see John Hagan, Marie Huxter \& Patricia Parker, "Class Structure and Legal Practice: Inequality and Mobility among Toronto Lawyers" (1988) 22 Law \& Soc'y Rev. 9; John Hagan \& Fiona Kay, Gender in Practice: A Study of Lawyers' Lives (New York: Oxford University Press, 1995); Heinz et al., ibid. Other American studies include Robert L. Nelson et al., "Observations from the After the Bar Survey of the Bar Class of 2000" (2006) 24 Quinnipiac L. Rev. 539. For England, see Richard L. Abel, The Legal Profession in England and Wales (Oxford: Basil Blackwell, 1988). 
practitioners in large cities, like foxes and racoons, survive and prosper in their new habitat by living on the margins. Survival and prosperity usually involve two strategies. First, they must provide efficient legal services at modest prices: this is achieved by routinizing work, delegating it to lay employees, and keeping overheads low. Second, they must exploit their non-legal advantages, such as close affinity with particular client communities, their familiarity as "repeat players" with the bureaucracies of civic governments or lower courts, or their access to financing or other services desired by clients. ${ }^{13}$

So we have specialists, general practitioners, and a variety of lawyers in other settings such as legal clinics, government offices, and corporate law departments. Now come three key points. The first is that these different kinds of lawyers do not simply know different things and serve different clienteles: they work in different practice settings; they receive different psychic and financial rewards; they are shaped by different professional cultures; and they are subject to what amounts de facto to different professional norms and governance structures. ${ }^{14}$

The second point is that while lawyers do move from one elite firm to another, to boutique firms, or to positions as in-house corporate counsel, there is relatively little movement into elite firms from general practice. Those who begin practice in small firms providing routine services for ordinary people are likely to remain in such firms for the rest of their careers. ${ }^{15}$

The third point is that the lawyers who inhabit these different practice roles do not represent a demographic cross-section of the profession. The "typical" lawyer is no longer a white, male, Anglo-Saxon, middle-aged generalist practising in a suburb or small town. There is no longer a "typical" lawyer. With urbanization, immigration, and feminization, the legal profession has indeed become diverse. The problem is that some lawyers are more "diverse" than others. Women remain under-represented in the higher echelons of elite law firms and over-represented in legal clinics, government jobs, and the ranks of in-house counsel. Members of recent immigrant communities are likely to be found most often in small, general practices, or in specialties, like immigration law, which serve their own communities. $^{16}$

13 See Heinz et al., ibid.

14 Harry W. Arthurs, "Legal Ethics: Ideology, Interest and Implementation of a Professional Ethical Code" in Don MacNiven, ed., Moral Expertise: Studies in practical and professional ethics (London: Routledge, 1990) 93; Harry W. Arthurs, "Climbing Kilimanjaro: Ethics for Postmodern Professionals" (1993) 6 Westminster Affairs 3; H.W. Arthurs, "The Dead Parrot: Does Professional Self-regulation Exhibit Vital Signs?" (1995) 33 Alta. L. Rev. 800; Harry W. Arthurs, "Lawyering in Canada in the 21st Century" (1996) 15 Windsor Y.B Access Just. 202 at 219-24 [Arthurs, "Lawyering in Canada"]. See also in the United Kingdom context, Andy Boon, John Flood \& Julian Webb, "Postmodern Professions? The Fragmentation of Legal Education and the Legal Profession" (2005) 32 J.L. \& Soc'y 473.

15 Barry D. Adam \& Kathleen A. Lahey, "Professional Opportunities: A Survey of the Ontario Legal Profession" (1981) 59 Can. Bar Rev. 674 at 683; Heinz et al., supra note 11. See also Ronit Dinovitzer \& Bryant G. Garth, "Lawyer Satisfaction in the Process of Structuring Legal Careers" (2007) 41 L. \& Soc'y Rev. 1, which suggests, however, that while lawyers in lower strata have less opportunity for career advancement, they report higher levels of job satisfaction than those in elite firms.

16 F.M. Kay, N. Dautovich \& C. Marlor, Barriers and Opportunities within Law: Women in a Changing Profession - A Longitudinal Survey of Ontario Lawyers 1990-1996, A Report to the Law Society of Upper Canada (Toronto: Law Society of Upper Canada, 1996); Hagan, Huxter \& Parker, supra note 12. More recent studies include Dinovitzer \& Garth, ibid.; Ronit Dinovitzer, "Social Capital and Constraints on Legal Careers" (2006) 40 L. \& Soc'y Rev. 445. 
To sum up, then, diversity in professional knowledge, experience, culture, and "success" is significantly determined, reinforced, and compounded by diversity in gender, religion, race, and ethnicity. That is what is meant by "stratification."

So far, I have tried to show how demographic change has transformed the economic context of legal practice, which in turn has radically altered - has in fact shattered - the knowledge base of the profession. The fragmentation of knowledge thus reinforces longstanding tendencies to stratification within the profession.

These developments - specialization, stratification, and the transformation of knowledge - are obviously going to have an effect on professional governance. To make a not very bold prediction: we will soon reach the point where a generic law degree will no longer suffice for admission to all kinds of practice; indeed, in some provinces, specialist credentials are already issued to those with practical experience and advanced knowledge of their field. ${ }^{17}$ To make a slightly bolder prediction: law societies will have to formally acknowledge that real estate lawyers, those who act for large corporations in merger and acquisitions (M \& A) transactions, and criminal lawyers in boutique firms, present quite different governance challenges in terms of enforcing fiduciary duties, requiring pro bono work, paying for malpractice insurance, or maintaining competence through mandatory continuing legal education. Law societies will also have to acknowledge that lawyers who work in large organizations, including large law firms, are usually subject to closer surveillance and sometimes held to higher performance standards by those organizations than by the law society itself. And to make the boldest prediction of all: law societies will ultimately have to acknowledge that the many new sub-professions of law are in any practical sense largely beyond their reach, and that they can best be regulated by bodies whose jurisdictions are defined by the new fault lines of an increasingly disparate and divided profession. Hence my first question: "Will the Law Society of Alberta Celebrate its Bicentenary?"

Now another development which also calls into question the longevity of existing forms of professional governance: the development of national and global markets for all goods and services, including legal services. ${ }^{18}$ In 1907, Alberta lawyers would have acted almost exclusively for individuals and local businesses, except for a few who were lucky enough to be retained by the banks, railways, or the government. Today, however, many lawyers in Alberta represent giant national and trans-national companies, or local companies closely linked to them on the food chain. ${ }^{19}$ These corporations operate on a scale larger than that of many states: they have complex legal needs; they can pay large fees to specialists to have those needs attended to; and they feel they are best served by lawyers who already have a good knowledge of their business rather than having to educate a new lawyer each time they need one. This logic explains the decline of solo practice and small partnerships that predominated the legal profession from its inception in 1907 until the first wave of large

In Ontario, the Law Society Act, supra note 3, s. 27, contemplates the creation of different classes of licenses to practice law for each of which a different "scope of activities" would be authorized in the bylaws of the Society.

18 Arthurs \& Kreklewich, supra note 1.

19 Pamela Fieber, "Big Business Beyond Bay Street" Canadian Lawyer 4 Students (March 2007), online: Canadian Lawyer $<$ http:/www.canadianlawyermag.com/index.php?option=com_content \& task=view\& id=100\&Itemid $=99999999>$. 
metropolitan and regional firms emerged in the 1960s and 1970s, closely followed by national law firms beginning in the $1980 \mathrm{~s}^{20}$

The growth of national law firms, in turn, had a significant impact on provincial and local legal cultures, institutions, and governance arrangements. Because of their large and affluent client base, national law firms could afford to assemble teams of specialists; because of their large revenues, they could afford the most advanced information technology and professional management practices; and because of their contacts outside the province, they were able to acquire knowledge of national, foreign, and international law, which enabled them to corner the market on transactions and disputes requiring such expertise. These advantages allowed them, in effect, to transform the local market for legal services. Local law firms could not compete with them, and consequently, had either to merge with an existing national firm, reinvent themselves as national firms, discover a local niche based on unique local connections or information, or face long-term decline.

The advent of national law firms also raised issues of professional governance. Key members of the firm - often leaders or prospective leaders of the local bar - would migrate across provincial boundaries to wherever they were needed, and sometimes, carried on their practice in more than one province. Provincial law societies could no longer justify the exclusion from practice of these peripatetic but prominent practitioners. ${ }^{21}$ Provincial and local bar associations suddenly had to contend with members whose professional contacts and concerns were no longer provincial or local. Local legal cultures, built around shared experiences and values, lost some of their capacity to shape professional behaviour, as key members moved away, or were increasingly influenced by experiences and values shared with their colleagues and counterparts in other jurisdictions.

Even the substance of local law was affected. Provincial law schools could no longer pretend to prepare people only for local practice; they had to design their curricula for graduates who would look for jobs in the new national and international markets for legal talent. Local academics understandably shifted their scholarly focus to issues with national or international salience..$^{22}$ Local legislators and regulators suddenly had to contend with lobbying and advocacy by lawyers whose imaginations were no longer dominated by local traditions and expectations, with lawyers who knew how things were done elsewhere, and with clients doing business worldwide, who often resented having to comply with

Arthurs, "Lawyering in Canada," supra note 14; Arthurs \& Kreklewich, supra note 1. See also Ronald J. Daniels, "Growing Pains: The Why and How of Law Firm Expansion" (1993) 43 U.T.L.J. 147.

21 In Black v. Law Society of Alberta, [1989] 1 S.C.R. 591, the Supreme Court of Canada struck down Law Society of Alberta (LSA) rules that, in effect, prohibited the formation of inter-provincial law firms, on the basis that they violated freedom of mobility under the Canadian Charter of Rights and Freedoms, s. 6(2)(b), Part 1 of the Constitution Act, 1982, being Schedule B to the Canada Act 1982 (U.K.), 1982, c. 11. For a comprehensive statement of current policies governing the inter-provincial and international movement of lawyers, see Federation of Law Societies of Canada (FLSC), Mobility of Lawyers in Canada, online: FLSC <http://www.flsc.ca/en/committees/mobility.asp>. 
idiosyncratic local regulatory regimes in fields such as securities, pensions, and employment standards. ${ }^{23}$

If I were to end my narrative here, I would have made a strong case that the development of national law firms has put into question the long-term survival of provincial law societies. At the very least I would have demonstrated the necessity of designing new national governance structures to complement, perhaps even eclipse, local governing bodies. However, there is another chapter to the story.

\section{GLOBALIZATION AND THE ERODING LOGIC of Local Professional Governance}

Globalization has also begun to call into question the future of those very same national law firms or, if not globalization in the broadest sense, then our increasing integration into a North American economic space dominated by the United States. This crucial development I have called "the hollowing out of corporate Canada." ${ }^{24}$ Let me first define my terms, and then explain the significance of "hollowing out" for Canada's lawyers and Alberta's in particular. "Hollowing out" has two dimensions. First, significant Canadian corporations, especially in the energy and resource sectors, have been bought out by large firms based in the U.S..$^{25}$ Second, other large companies, especially in manufacturing, have been reorganized so that their well-established Canadian subsidiaries enjoy far less functional autonomy than they used to. ${ }^{26}$ The result of these two developments is that there are fewer Canadian corporate head offices than previously, and that those which have survived often have less need for high-end legal services than they used to. Moreover, Canadian firms in the financial services sector, in commercial real estate, advertising, accounting, consulting, and other socalled "business services," also face a loss of clientele, and consequently a diminishing need for lawyers. And even when they do need lawyers - to apply for a trademark, say, or to float an initial public offering of equities - the value-added contributed by their Canadian lawyer

23 See e.g. the Canadian Bar Association's (CBA) position on the regulation of securities markets, pensions, and labour markets: CBA, National Business Law Section, Modernizing Securities Transfer Rules in Federal Statues (November 2007), online: CBA <http://www.cba.org/CBA/submissions/pdf/ 07-53-eng.pdf>; CBA, National Pensions and Benefits Section, "Re: Solvency Funding Relief Regulations," Submission Letter to Department of Finance Canada (13 July 2006), online: CBA $<$ http://www.cba.org/CBA/submissions/pdf/06-33-eng.pdf>; CBA, National Labour and Employment Law Section, "Re: Review of Federal Labour Standards," Letter to Federal Labour Standards Review (21 October 2005), online: CBA <http://www.cba.org/CBA/ submissions /pdf/ 05-44-eng.pdf>.

24 Harry W. Arthurs, "The Hollowing out of Corporate Canada?" in Jane Jenson \& Boaventura de Sousa Santos, eds., Globalizing Institutions: Case Studies in Regulation and Innovation (Aldershot, U.K.: Ashgate, 2000) 29.

25 Statistics Canada, Corporations Returns Act: 2005 (Ottawa: Ministry of Industry, 2007), online: Statistics Canada <http://www.stat can.ca/cgi-bin/downpub/listpub.cgi?catno $=61-220-X I E 2005000>$ at 6, 15: In 2005, foreign-controlled corporations accounted for 29.9 percent of corporate operating revenues and 21.2 percent of corporate assets, a figure that has remained constant since 1999 . Of foreign-controlled corporations in non-financial sectors, the U.S. accounts for 68.5 percent of all operating revenues and 46 percent of assets. For a list of major mergers involving Canadian firms between 2000-2006, see "The urge to merge" CBC News (26 February 2007), online: CBC News $<$ http://www.cbc.ca/news/background/mergers/>.

26 Isaiah A. Litvak, The Marginalization of Corporate Canada (Toronto: Canadian Institute of Foreign Affairs, 2001). 
has been diminished to the extent that Canadian securities and intellectual property legislation has been brought closely into line with that of the U.S. ${ }^{27}$

To be clear, I am neither attacking nor defending globalization in general, or continental economic integration under the North American Free Trade Agreement Between the Government of Canada, the Government of Mexico, and the Government of the United States $^{28}$ in particular. Rather, I am offering an hypothesis about the possible effects of our new political economy on the prospects of Canadian lawyers. If my hypothesis proves to be correct, law firms in Calgary, Edmonton, Toronto, and Montreal, which used to provide highend legal services to important locally-based corporations, will have to start looking elsewhere for clients.

Where might they look? One place, of course, is to the new foreign-based corporations which increasingly dominate some sectors of the Canadian economy. In the short term, this tactic will prove successful. When companies are merged, acquired, or restructured, there is lots of one-off work for corporate, pension, real estate, and securities lawyers. ${ }^{29}$ But over time, as the new corporate arrangements are set in place, Canadian lawyers will gradually be replaced on key files by lawyers retained in Chicago or Houston by global head offices located in those cities. Major Canadian law firms may then try to restore their client base by poaching clients from their direct competitors. This strategy again may succeed in the shortterm, but in the long-term, as the number and the autonomy of surviving Canadian corporations continues to dwindle, there will be fewer and fewer clients left to poach. A third strategy for national law firms is to reinvent themselves as international firms, ${ }^{30}$ or to become the Canadian affiliate of international firms based in New York or London. ${ }^{31}$ This is an intriguing possibility, but so far, results have been rather disappointing. Canadian firms can only survive abroad if they can ride the coat-tails of Canadian corporate clients doing business in Shanghai, Frankfurt, or Bangalore. The problem is that not very many Canadian businesses are doing business in such exotic locales. Thus, while a few Canadian law firms have managed to gain a toehold in the U.S., and a few in the United Kingdom and Asia, they seem to have had difficulty in sustaining momentum.

Thus, the hollowing out of corporate Canada may turn out to be the hollowing out of legal Canada as well. This would be a severe disappointment for people who hoped that the emergence of national markets, corporations, and law firms might provide Canada with concentrations of wealth and talent, with economies of scale, and with the new thinking

Arthurs, "The State We're In," supra note 1; Arthurs \& Kreklewich, supra note 1; Arthurs, "Lawyering in Canada," supra note 14; Harry W. Arthurs, "Poor Canadian Legal Education: So Near to Wall Street, So Far From God" (2000) 38 Osgoode Hall L.J. 381. For U.S. and Commonwealth comparisons, see Fiona Cownie, ed., The Law School - Global Issues, Local Questions (Aldershot, U.K.: Ashgate, 1999). 17 December 1992, Can. T.S. 1994 No. 2, 32 I.L.M. 289 (entered into force 1 January 1994).

Marzena Czarnecka, "The Top 15 Canada/US Cross-Border Deals of 2004" Lexpert (April 2005) 60; Marzena Czarnecka, "The Top 10 Corporate Deals of 2006" Lexpert (January 2007) 64; “Top 10 M\&A deals" The Globe and Mail (18 July 2007) B8.

30 Torys LLP became the first Canadian law firm with a significant presence in the U.S. when it merged with the New York firm Haythe \& Curley. For background, see Timothy G. Leishman, "First We Take Manhattan: Law Firm Merger Strategy" Lexpert (March 2000) 62; John Alexander Black, "The Tory Marque" Lexpert (November 1999) 8.

31 On the recent merger between Fasken Martineau DuMoulin LLP and the London firm Stringer Saul LLP, see Julius Melnitzer, “Nice Move” Lexpert (February 2007) 90. 
necessary to build a successful economy and a compassionate society. Ironically, however, the demise of corporate Canada and the disappearance of national law firms might leave us back where we began a century ago: with a profession devoted to the simple problems of local clients - not a bad thing in itself, but not a happy prospect for over-invested law firms and ambitious lawyers. If that is the trajectory of Canada's legal professions, it becomes more likely that governing bodies in 2107 will still be provincial. Whether they will also be parochial depends a great deal on the next and final theme I will explore.

\section{HyPhenated Professionalism: \\ The Most Fundamental Challenge to Professional Governance}

That theme involves what I will call "hyphenated professionalism." As I suggested earlier, professionalism involves two main aspects: a unique base of knowledge, and a regulated monopoly over the use of that knowledge. What happens, then, when lay people gain access to knowledge that formerly was exclusively possessed by professionals, and when lawyers lose or surrender their monopoly over the use of such knowledge?

De-professionalization is my first example. ${ }^{32}$ Lay people today can acquire legal knowledge which they formerly would have had to buy from a lawyer. Bookstores sell selfhelp books and the internet has become an infinite font of legal wisdom. Service providers and paralegals incorporate companies, litigate traffic tickets, and represent would-be immigrants and injured workers before specialized tribunals. Law firms and law societies themselves legitimize de-professionalization, if they do not actively promote it, by delegating many legal functions to law clerks and, in Ontario at least, by undertaking to credentialize and regulate them. ${ }^{33}$ The net effect is that the legal profession has gradually surrendered its monopoly over many of the tasks that it used to perform or control.

The causes of de-professionalization are pretty obvious: people are more educated than they used to be and have greater confidence in handling their own affairs; many legal procedures have been simplified and standardized to the point where they can be easily mastered by people who lack formal training in law; and information technology has made legal knowledge almost as accessible to lay people as it is to lawyers themselves. And there is one more reason: lawyers are unwilling or unable to deliver certain kinds of standard services at prices that most people can afford. Of course, de-professionalization is fraught with risks. Law clerks, legal agents, service providers, and especially individuals representing themselves can overlook complexities, make mistakes, and exacerbate disputes. On the other hand, they generally do not do so; and lawyers sometimes do.

De-professionalization, whatever its causes and consequences, raises difficult issues for law societies. How can they fight to protect a monopoly over knowledge which clients -

See e.g. Robert A. Rothman, "Deprofessionalization: The Case of Law in America" (1984) 11 Work and Occupations 183; Abel \& Lewis, supra note 2; Richard A. Posner, "The Deprofessionalization of Legal Teaching and Scholarship" (1993) 91 Mich. L. Rev. 1921; Boon, Flood \& Webb, supra note 14.

33 Under the Access to Justice Act 2006, S.O. 2006, c. 21, the Law Society of Upper Canada (LSUC) acquired power to regulate paralegals in Ontario. See also: LSUC, Task Force on Paralegal Regulation, Report to Convocation (23 September 2004), online: LSUC $<$ http://www.lsuc.on.ca/media/convsept04_ paralegal_report.pdf $>$. 
the supposed beneficiaries of monopoly - are keen to access directly? How can they insist on the exclusive right of lawyers to deliver certain kinds of services when lawyers retained to deliver those services insist on delegating them to law clerks? And how can the provision of services no longer within the profession's monopoly be regulated to ensure that consumers are protected and unscrupulous service providers are banned from the market?

It would be rash to predict that the profession's monopoly over routine legal procedures and transactions will continue to erode to the point where there is no monopoly left at all. But in the past hundred years, things which were once the staples of legal practice have ceased to be, and the trend seems unlikely to abate.

Indeed, the trend seems likely to move upmarket, which brings me to the second of my hyphens, multi-professionalism. As I have already suggested, many legal specialists work in close collaboration with experts in other disciplines. That collaboration is organized either through free-standing, multi-disciplinary practices or, in states which do not permit such practices, through large consulting firms. Indeed, several consulting firms employ so many lawyers that they rank amongst the largest law firms in the world. ${ }^{34}$ Sometimes, too, law firms in Canada and elsewhere build up their own in-house consultancies, in which lawyers work alongside economists, planners, other professionals. And sometimes, members of several professions simply work together within the departmental structures of large business corporations.

There is a powerful logic to multi-professional or multi-disciplinary practice.$^{35}$ It enhances the likelihood that all relevant skills and knowledge will be mobilized to address the problem at hand; it reduces the likelihood that members of one profession will play a dominant role to the prejudice of another, and ultimately, of the client; it forces all professional participants to rethink the unexplored assumptions of their own discipline or profession in ways which can lead to useful innovation; and of course it can be, should be, more cost-effective for clients.

Professional governing bodies, however, have been reluctant to allow lawyers to participate in multi-disciplinary practices other than those clearly controlled by members of the bar. ${ }^{36}$ The ostensible reason is that members of other professions cannot be held to the

Figures are found in John Flood, "Capital Markets: Those Who Can and Cannot Do the Purest Global Law Markets" in Richard P. Appelbaum, William L.F. Felstiner \& Volkmar Gessner, eds., Rules and Networks: The Legal Culture of Global Business Transactions (Oxford: Hart, 2001) 249 at $259 \mathrm{ff}$.

See Kent Roach \& Edward M. Iacobucci, "Multidisciplinary Practices and Partnerships: Prospects, Problems and Policy Options" (2000) 79 Can. Bar Rev. 1; Harry McVea, "Predators and the Public Interest — the 'Big Four' and Multi-Disciplinary Practices” (2002) 65 Mod. L. Rev. 811; Michael Trebilcock \& Lilla Csorgo, "Multi-Disciplinary Professional Practices: A Consumer Welfare Perspective," (2001) 24:2 Dal. L.J. 1. For a recent sociological analysis, see George C. Nnona, "Situating Multidisciplinary Practice Within Social History: A Systemic Analysis of Inter-Professional Competition" (2006) 80 St. John's L. Rev. 849.

36 Multi-disciplinary practices (MDPs) have been permitted in Ontario, as long as they are controlled by law firms, and rejected outright in some other Canadian provinces. See e.g. LSUC, Multi-Disciplinary Practice Task Force, Report to Convocation (21 September 2000), online: LSUC <http://www.lsuc.on. $\mathrm{ca} / \mathrm{media} /$ mdptaskreport.pdf $>$; Law Society of British Columbia (LSBC), "Benchers say no to multidisciplinary practice" Benchers' Bulletin (November-December 2001), online: LSBC <http://www. lawsociety.bc.ca/publications_forms/bulletin/2000-01/01-12-14_mdp.html $>$. However, MDPs have 
same high ethical standards as lawyers. While this reasoning is somewhat suspect as a veiled effort at market control, the Enron scandal and others involving the "big five" (or "four" or "three") international consulting firms certainly dampened enthusiasm for multi-professional practices in Canada and elsewhere.

The question is whether the advantages mentioned earlier will ultimately lead to a revival of their credibility and popularity. That is what is going to happen, I believe: multidisciplinary practices are coming to Canada and the U.S., just as they have come to some European countries, and very recently, to England. ${ }^{37}$ Law societies will therefore have to find a way to cope with the new reality that many lawyers will be collaborating more closely with colleagues in other professions than they do with fellow lawyers. Obviously, there are difficulties. At least in the short run, the governing body of each profession will have to restrict its regulatory activities to its own members. And in light of the different histories of the professions, each of the governing bodies is likely to have its own special view of how to regulate honesty, confidentiality, conflicts of interest, and especially, competence. However, sooner, rather than later, we are likely to find that regulation is being exercised by or under the supervision of an umbrella body whose mandate extends to all members of multi-professional or multi-disciplinary practices. In the long run, it seems quite possible that the boundaries amongst the professions will begin to dissolve.

This leads me to my third example of hyphenated professionalism: "postprofessionalism." 38 The idea of post-professionalism is pretty simple, but its implications are far-reaching. Essentially, the argument runs, professional boundaries laid down in earlier times no longer have much meaning in the context of our post-industrial, knowledge-based economy. All information, all learning, and all skills relevant to the solution of a given problem should be mobilized for the purpose, and can be mobilized, thanks to new information technologies. However, unlike multi-professional firms, in which each member contributes from within the defined territory of his or her profession, post-professionalism envisages that individual practitioners will be able to do whatever they have the inclination and capacity to do. In a post-professional world, clusters of professions - broadly construed to include all knowledge-based occupations - will dissolve into each other. What postprofessional practitioners will have in common is their general knowledge of a social,

generally been accepted in a number of European countries and, more recently, in the U.K. See also Julius Melnitzer, "MDPs Revisited” Lexpert Magazine (July-August 2001) 98.

37 Legal Services Act 2007 (U.K.), c. 29, Part 5 (received royal assent 30 October 2007). The Solicitors Regulation Authority (SRA) predicts that a licensing regime for alternative practice structures, including MDPs will be in place by 2011 or 2012: SRA, Legal Services Act: New forms of practice and regulation (November 2007), online: SRA < http://www.sra.org.uk/securedownload/file/350 > at 3. For the evolution of thinking concerning MDPs within the English legal profession, see Sir David Clementi, Review of the Regulatory Framework for Legal Services in England and Wales: Final Report (London: Department of Constitutional Affairs, 2004), online: Legal Services Review < http://www.legal-servicesreview.org.uk/content/report/report-chap.pdf>.

38 See Herbert M. Kritzer, Legal Advocacy: Lawyers and Non-Lawyers at Work (Ann Arbor: University of Michigan Press, 1998) at 216-23; Herbert M. Kritzer, "The Professions are Dead, Long Live the Professions: Legal Practice in a Postprofessional World” (1999) 33 L. \& Soc'y Rev. 713; Russell G. Pearce, "Law Day 2050: Post-Professionalism, Moral Leadership, and the Law-as-Business Paradigm" (1999) 27 Fla. St. U.L. Rev. 9; more generally, Edgar Burns, "Developing a Post-Professional Perspective for Studying Contemporary Professions and Organisations" (Paper presented at the 5th International Critical Management Studies Conference, Manchester, U.K., 11 July 2007) [unpublished]. 
economic, or technical field, and the ability to recognize its problems, to find solutions, and to know when to seek help from someone with specialized knowledge.

This is not an entirely far-fetched scenario. In fact, it is a reasonably accurate description of the way many lawyers practice today: working far outside the boundaries of their formal legal knowledge; providing strategic advice based on their experience and specialized knowledge of other fields; assembling ad hoc teams of collaborators; and, as suggested earlier, seeing the "client" community as their relevant other, rather than the legal profession. It is also a description of the way in which many students are already pursuing their "legal" educations: taking advanced degrees in other disciplines before or after law school, taking courses in other faculties while studying law, or reading materials from other disciplines as part of their regular law courses.

So legal professionalism is being redefined by three hyphens and three prefixes: de-, multi-, and post-. In each case, a change in the nature, distribution, and deployment of knowledge is detaching lawyers from their familiar, historical roles as advice-givers and advocates who "own" a monopoly over a particular field of human endeavour because they "own" a monopoly over a particular kind of knowledge. Because law societies are mandated to police that monopoly, prevent its abuse, and ensure its use in the public interest, this represents a challenge to their very existence.

\section{Conclusion}

I have tried to show how developments external to the legal profession are leading to internal changes which are likely to threaten its knowledge base, its monopoly, its governance structures, and perhaps its very existence. I have mentioned three specific examples of such developments: changing demography, globalization, and the dissolution of professional boundaries. I could have mentioned many more: climate change, technology, juridification, the privatization of law production, and new ideas about states and markets come immediately to mind. Thus the question confronting Canadian lawyers, and their governing bodies, is not simply whether, or even how, law societies will be affected by these transformative developments, it is whether they can survive them at all. 